\title{
Nematode parasites in the striped mullet (Mugil cephalus Linnaeus, 1758) in the southern Gulf of California
}

\author{
Ana R. Álvarez-Sánchez ${ }^{1}$, Yuniel Méndez-Martínez ${ }^{1}$, Juan José Reyes-Pérez ${ }^{1}$ \\ Carlos R. Romo-Quiñonez ${ }^{2}$ \& Galdy Hernández-Zárate ${ }^{3}$ \\ ${ }^{1}$ Facultad de Ciencias Pecuarias, Universidad Técnica Estatal de Quevedo (UTEQ) \\ Quevedo, Los Ríos, Ecuador \\ ${ }^{2}$ Centro de Investigaciones Biológicas del Noroeste (CIBNOR), La Paz, B.C.S. México \\ ${ }^{3}$ Colegio de Postgraduados-Campus Veracruz, Postgrado en Agroecosistemas \\ Tropicales, Veracruz, México \\ Corresponding author: Ana Ruth Álvarez-Sánchez (dra.arasanchez@gmail.com)
}

\begin{abstract}
Coastal lagoons are an important component of the Gulf of California as they are considered natural ecosystems with high productivity and home to species of regional economic interest such as the striped mullet (Mugil cephalus), which, for its eating habits tends to present parasitism. The objective of the present work was to identify and determine the number of nematode parasites in the striped mullet in three lagoon systems (Navachiste, La Reforma, and Ceuta) in coastal areas of the southern Gulf of California. Thirty Mugil cephalus were randomly obtained from each of the lagoon systems. From each fish was obtained the total length, weight and condition factor (FC), next was dissected to be analyzed hepatosomatic index (HSI) and determine by direct count the prevalence, average intensity and average abundance of nematode; nematodes are identified taxonomically and molecularly. The nematode parasites found to belong to the genus Contracaecum of the family Anisakidae in all the fish sampled the parasitic prevalence was $67 \%$. The nematode parasites found by sex indicated that $77 \%$ of the striped mullet females analyzed were parasitized, while the males presented $59 \%$. The CF obtained was 1.17-4.07, and the HSI ranged between 0.85 and 1.45 ; the average intensity for nematodes was 7.45 , and the average abundance was 4.97 , demonstrating that Contracaecum multipapillatum is the main nematode parasite present in all lagoon systems the southern Gulf of California.
\end{abstract}

Keywords: Mugil cephalus; infestation; liver; parasitism; lagoon system; Gulf of California

\section{INTRODUCTION}

The Gulf of California is the most studied body of water in all of Mexico, considered a national heritage due to its hydrological, geological, biological and fishing characteristics (Ayala-Bocos et al., 2016; PadillaSerrato et al., 2017). Coastal lagoons are an important component of the gulf in question since they are considered natural ecosystems with high productivity; which is due to the different activities of the primary and secondary producers; in addition to this, their hydrological and ecological characteristics make them areas with rich habitats and a high rate of biodiversity (Sánchez-Lindoro et al., 2017). There are characterized by having a passive transport of suspended sediments, organic and inorganic nutrients, a condition that has propitiated the ideal environment for various species of fish, crustaceans, mollusks and bivalves of great commercial interest (Herrera-Valdivia, 2016).

One of the most important resources of coastal fishing in lagoon systems, bays and estuaries on the Mexican Pacific coast, is the species of the family Mugilidae, and within them, the striped mullet (Mugil cephalus), which has a wide distribution, It inhabits the coastal waters of most tropical and subtropical regions. In the western Atlantic Ocean, it is found from Nova Scotia, Canada, to Brazil, including the Gulf of Mexico. It is absent in the Bahamas and the Caribbean. In the eastern Atlantic, it lives from Biscay Bay (France) to South Africa, including the Mediterranean Sea and the Black Sea. The distribution of the eastern Pacific Ocean extends from southern California to Chile (FAO, 2006; Colín-Martínez, 2014; Fernández, 2014). 
The feeding of the Mugilidae is characterized by being an important ecological link in the energy flow within the estuarine communities, since they feed by sucking the surface layer of sediments, which are removed by organic detritus, filamentous algae and, occasionally, ostracods, nematodes, foraminifera, microgasteropods, annelids, isopods, plant fragments and benthic diatoms (Salvarina et al., 2018). Therefore, they are considered by various authors as detritivores, iliophages, vegetarians, omnivores, phytophages and zooplankters (Verdiell-Cubedo et al., 2007; Dankwa et al., 2015; Villanueva-Gómez et al., 2016). This type of feeding propitiates to elevate the parasitic incidence of nematodes (Villanueva-Gómez, 2016).

The infections by nematodes in the mullets are produced mainly by species of the Anisakidae family (Castellano et al., 2017; Valles-Vega et al., 2017); these are roundworms (Ajala \& Fawole, 2014; Gaber et $a l ., 2015)$. Sometimes the presence of these parasites in the mullet does not generate important physiological alterations (Dione et al., 2014; Maldonado \& Godoy, 2014). However, when they are caused, the observed effects may be oxidative stress, tissue damage, immunosuppression and endocrine disruption, which affect the population of mullet and the fishing industry (Valles-Vega et al., 2017).

In the human being, conditions such as anisakiasis and hypersensitivity reactions due to allergens of the parasites can be caused; this is attributed to the consumption of raw or undercooked fish (Shamsi et al., 2017; Castellanos et al., 2018; Martins et al., 2018; Shamsi et al., 2018a,b). That is why works for the monitoring and identification of nematodes that parasitize species of commercial importance is important. The objective of this work is to identify and determine the parasitic prevalence of nematodes in the striped mullet M. cephalus in three coastal areas of the southern Gulf of California (Mexico).

\section{MATERIALS AND METHODS}

The lagoon systems analyzed were: Lagoon Navachiste Complex of San Ignacio Macapule $\left(25^{\circ} 48^{\prime}-25^{\circ} 78^{\prime} \mathrm{N}\right.$, $\left.109^{\circ} 02^{\prime}-108^{\circ} 55^{\prime} \mathrm{W}\right)$, located in the southwest area of the Gulf of California, Mexico (Montes et al., 2011); Lagunar System Colorada-Santa María-La Reforma Beach $\left(25^{\circ} 17^{\prime}-24^{\circ} 42^{\prime} \mathrm{N}, 108^{\circ} 25^{\prime}-107^{\circ} 57^{\prime} \mathrm{W}\right)$, located in the north-central coast of Sinaloa, in the Municipalities of Guasave, Angostura and Navolato; and, the lagoon system of Ceuta $\left(24^{\circ} 15^{\prime}-23^{\circ} 55^{\prime} \mathrm{N}, 107^{\circ} 24^{\prime}\right.$ $\left.106^{\circ} 58^{\prime} \mathrm{W}\right)$, which is located in the south center of Sinaloa, in the municipalities of Culiacán and Elota, north of the Elota River and parallel to the Quevedo Peninsula (Romero-Beltrán et al., 2014).
For each lagoon system, 30 striped mullet (Mugil cephalus) were randomly obtained directly from local fishers in the months of March-May 2018. The individuals were measured with an ichthyometer Krauss \& Henke $( \pm 0.1 \mathrm{~mm}$; KH-PISCIS-50-22, Apopka, FL, USA) of $60 \mathrm{~cm}$ and weighed with a digital balance $( \pm 0.1 \mathrm{~g}$; Ohaus Scout Pro SP2001, Pine Brook, NJ, USA). From each organism, the total length (LT, $\mathrm{cm})$ and the total weight $(\mathrm{W}, \mathrm{g})$ were obtained.

The organisms were cut longitudinally from the operculum to the anal cavity. The striped mullet were sexed based on Marín et al. (2003) and examined under a stereomicroscope Nikon SMZ-10 to examine their different external and internal anatomical structures and thus obtain direct and accurate counts of the existing, visible nematodes. The tissues analyzed were the exogenous part of the organism, gills, liver, abdominal cavity and muscle tissue. The identification of the parasites was based on Martins et al. (2005) and Shamsi et al. (2017). Taxonomic characteristics were considered: the number of paracloacal papillae, the pattern of distribution of the papillae and the length of the spicules. The health status of the fish was quantified, according to Ashfield et al. (1998) and Cabrera-Páez et al. (2008):

Condition factor $(\mathrm{FC})=$ weight length ${ }^{-3} \times 100$

Hepatosomatic index $(\mathrm{HSI})=($ liver weight $/$ total fish weight) $\times 100$

Prevalence $=$ number of parasitized fish/total fish analyzed

Average intensity $=$ total parasites/number of infected fish

Mean abundance $=$ number of parasites/total fish examined

The values are presented as means \pm standard deviation (SD). The Kolmogorov-Smirnov $(P<0.05)$ and Bartlett $(P<0.05)$ tests were applied before the statistical analyses. Morphometric indicators, number of nematode parasites and nematode parasites by tissue in the striped mullet were analyzed by a one-way ANOVA. When significant $F$ values were observed, the multiple comparisons of means were made (Tukey multiple comparisons test was used to compare differences between means, at $P<0.05$ ). Pearson correlation was used to determine if there is an association between the number of parasites with size, weight and sex, and prevalence of parasites between lagoons or host sex. The statistical Minitab 18 software (Minitab Inc., Philadelphia, PA, USA) was used. All percentage data were arcsine transformed before statistical analyses. 


\section{Molecular identification}

For the molecular analysis of the nematodes, the protocol described by Valles-Vega (2014) and Zhu et al. (2000) where the primers of the first internal transcribed spacer (ITS-1) and the second internal transcribed spacer (ITS-2) of the ribosomal DNA (rDNA) were used.

\section{Extraction of DNA (Valles-Vega, 2014)}

The DNA extraction was performed with approximately $0.5 \mathrm{~cm}^{3}$ portions of nematode tissue. Samples were macerated and added $3 \mu \mathrm{L}$ of proteinase $\mathrm{K}$ subsequently incubated at $35^{\circ} \mathrm{C}$ for one hour. $200 \mu \mathrm{L}$ of CTAB buffer $(2 \%(\mathrm{w} / \mathrm{v})$ CTAB, $2 \%$ PVP, $0.5 \% \beta-$ mercaptoethanol, $1.4 \mathrm{M} \mathrm{NaCl}, 20 \mathrm{mM}$ EDTA, $100 \mathrm{mM}$ Tris-Hcl, $\mathrm{pH} 8$ ) were added. They were incubated at $65^{\circ} \mathrm{C}$ for $5 \mathrm{~min}$ and then homogenized in the vortex at maximum speed for $1 \mathrm{~min} .600 \mu \mathrm{L}$ of the CTAB buffer was added and incubated at $65^{\circ} \mathrm{C}$ for one hour. We added $700 \mu \mathrm{L}$ of chloroform: isoamyl alcohol. The samples were centrifuged (Centrifuge Eppendorf, 5425, USA) at $21,330 \mathrm{~g}$ at $14^{\circ} \mathrm{C}$ for $10 \mathrm{~min}$ at room temperature; the aqueous phase is recovered in a new tube. We used $300 \mu \mathrm{L}$ of cold isopropanol and $50 \mu \mathrm{L}$ of $7.5 \mathrm{M}$ ammonium acetate to precipitate the DNA, and the samples were left at $-20^{\circ} \mathrm{C}$ overnight. The DNA was recovered by centrifugation at $21,330 \mathrm{~g}$ at $4^{\circ} \mathrm{C}$ for 20 min, the supernatant was discarded, and the concentrate or button was washed with $50 \mu \mathrm{L}$ of $70 \%$ ethanol, the samples were centrifuged again at $21,330 \mathrm{~g}$ at $4^{\circ} \mathrm{C}$ for $10 \mathrm{~min}$, and the supernatant was discarded. The DNA button was allowed to dry and re-suspended in $50 \mu \mathrm{L}$ of TE.

\section{Amplification and sequencing}

The samples were amplified with the polymerase chain reaction (PCR), where the reaction was adjusted to 50 $\mu \mathrm{L}$. With the ITS- 1 and ITS-2, the NC5 start primer (5'GTA GGT GAA CCT GCG GAA GGA TCAT-3') and the NC2 reverse primer (5'TTA GTT TCT TCC TCC GCT-3') were used in the study by Zhu et al. (2000) and Valles-Vega (2014), obtaining an amplicon of $\sim 1,000$ base pairs. The PCR conditions were: $10 \mathrm{~min}$ at $95^{\circ} \mathrm{C}$ (start denaturation), 30 cycles of $30 \mathrm{~s}$ at $95^{\circ} \mathrm{C}$ (denaturation), $40 \mathrm{~s}$ at $52^{\circ} \mathrm{C}$ (alignment), $75 \mathrm{~s}$ at $72^{\circ} \mathrm{C}$ (extension) and $7 \mathrm{~min}$ at $72^{\circ} \mathrm{C}$ of final elongation. Finally, the products were visualized in a $1 \%$ agarose gel, stained with Red GEL, and the DNA bands were visualized in a photo documenter. The PCR product was sent to purify and sequence the company MacroGen (Korea).

\section{RESULTS}

In the present study of parasitic prevalence by nematodes in three coastal lagoons of the southern Gulf of California, it was found that the general presence of parasites, corresponding to the 90 striped mullet fish Mugil cephalus sampled, is of $67 \%$ (Fig. 1a). The analysis of the individual prevalence by lagoon system indicated that $70 \%$ of the organisms sampled, from the Navachiste Lagoon system, were parasitized. The same percentage was observed in the lagoon system of Colorada-Santa María-La Reforma Beach, and the lowest percentage was observed in Ceuta with $60 \%$ of parasitized organisms (Fig. 1b); although these differences were not statistically significant since a value of $\mathrm{F}=0.683, P=0.468$ was obtained.

The average intensity for nematodes was 7.45 , and the average abundance of 4.97 . The nematode parasites found by sex indicated that $77 \%$ of the females analyzed were parasitized, whereas males presented $59 \%$ difference that was not significant, obtaining an $\mathrm{F}$ $=0.771, P=0.126$. No correlation was found in the Pearson analysis $0.281(P=0.126)$. The individual analysis by the coastal lagoon is shown in Figure 2. At Navachiste, $75 \%$ of the females analyzed for this study were parasitized and in a lower ratio the males with 67\%; for the La Reforma Lagoon system, the females presented $100 \%$ nematode parasites while in males only 50\% were infected; for the Ceuta Lagoon system there was no distinction between the number of nematodes by sex (60\%) for both males and females (Fig. 2).

The analysis of nematodes presence by tissue (abdominal cavity, muscle tissue, liver, gills), showed significant differences $(\mathrm{F}=9.32, P=0.037)$. The abdominal cavity presented the highest number of nematodes in fishes of the La Reforma coastal lagoon (37 nematodes), and to a lesser extent, in the Ceuta Lagoon (22 nematodes) (Fig. 3). The second tissue with the highest presence of nematodes was the liver, showing the highest values in fishes from La Reforma and Navachiste (14 nematodes); in muscle tissue, it was observed that Navachiste and Ceuta had the highest number of parasites nematodes; in gills, the nematodes of La Reforma and Navachiste were statistically different from those of Ceuta (Fig. 3).

A strong positive correlation was found between the number of nematodes and the size $(\mathrm{cm})$ of the mullet (0.756, $P<0.0001)$. Similar results were observed between the correlation of the number of nematodes and the weight $(\mathrm{g})$ of the organisms, where values of $\mathrm{P}$ $=0.741(P<0.0001)$ were shown. Also, the condition factor (FC) was determined in M. cephalus, obtaining the highest value of 4.07 and the lowest of 1.17 in the coastal lagoon Ceuta and Navachiste; the HSI oscillated between 0.85 and 1.45 respectively (Table 1$)$. The correlation between both factors was negative -0.452 ( $P$ $=0.012$ ). 


\section{a}

b
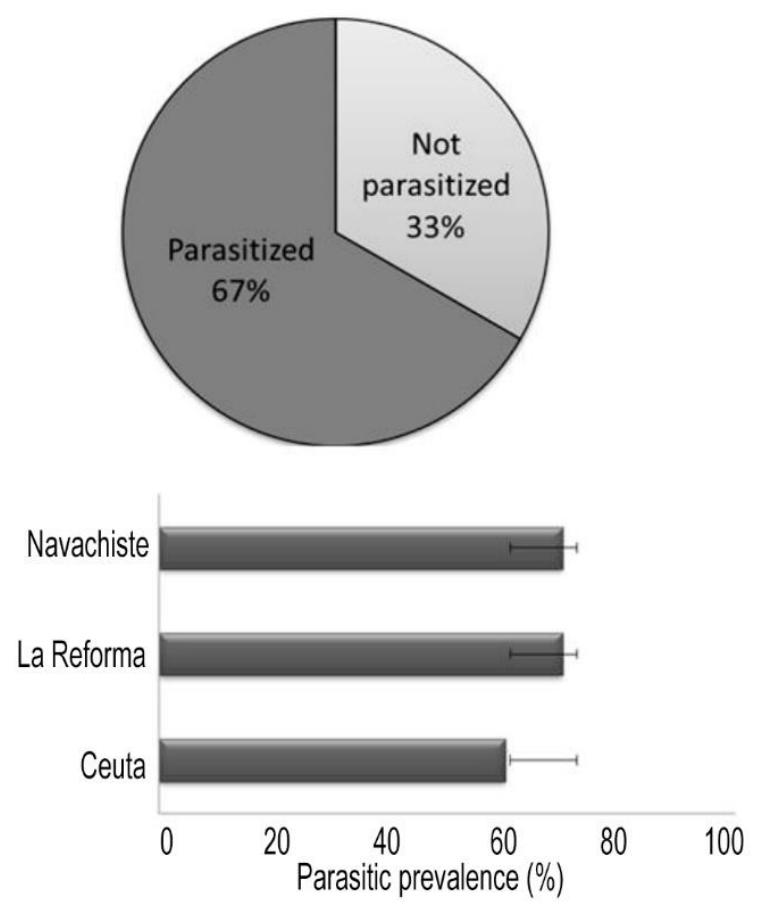

Figure 1. Parasitic prevalence by nematodes in striped mullet (Mugil cephalus) in three lagoon systems of the southern Gulf of California: Navachiste, La Reforma and Ceuta. a) Prevalence of nematodes in the three coastal lagoons, b) individual prevalence by coastal lagoon. Nonsignificant differences between the numbers of parasites found in coastal lagoons $(P>0.05)$.

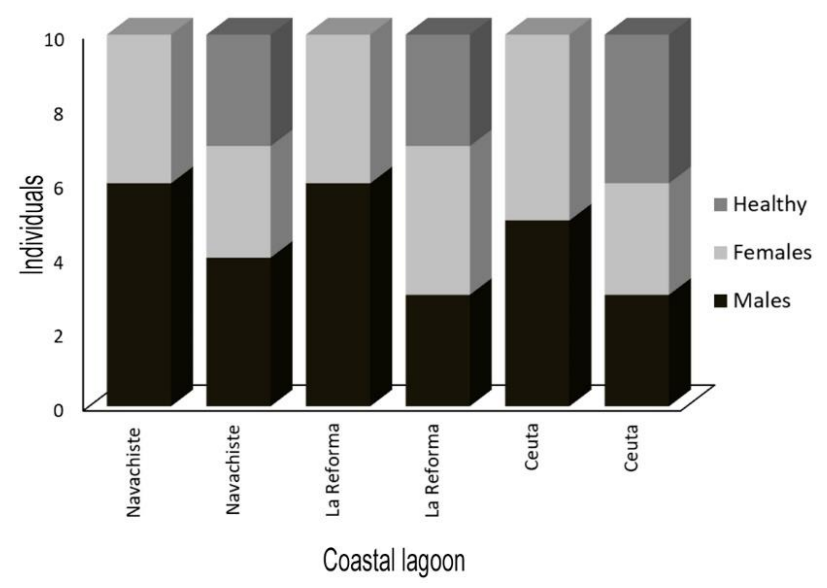

Figure 2. Parasitic incidence by sex in striped mullet (Mugil cephalus) in three coastal lagoons of the southern Gulf of California.

It was observed that, out of 90 specimens of striped mullet collected, only one species of parasitic nematode Contracaecum multipapillatum with greater abundance was found in the section of the abdominal cavity of the fish. The morphological characteristics of nematodes observed were: three lips, one dorsal with a double pa-

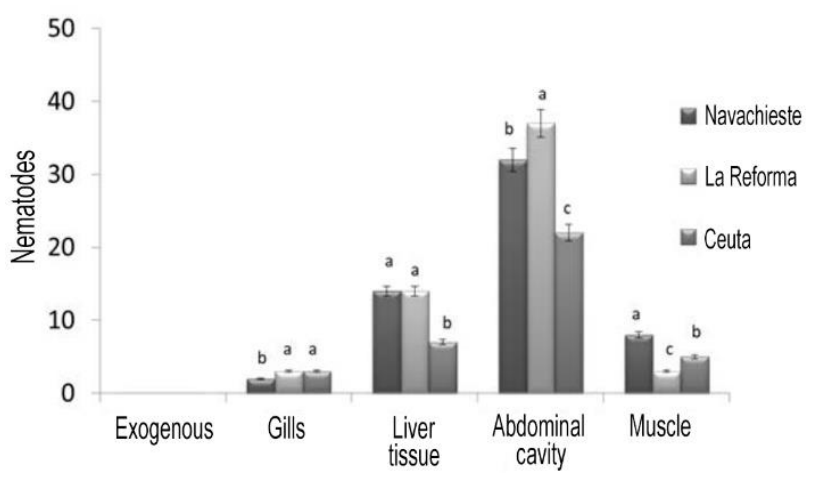

Figure 3. Nematode parasites by tissue analyzed in striped mullet (Mugil cephalus) in three coastal lagoons of the southern Gulf of California. Equal letters indicate that there are no significant differences $(P>0.05)$ between the numbers of parasites found by tissue.

pilla and two ventrolateral with a slight depression in the upper margin, each with a double papilla, absent dentigerous crests. The three interlabios, well developed, with a rounded tip and not bifurcated. Excretory pore in the base of the lips. Muscular esophagus and a globular glandular ventricle. Blind esophageal and intestinal present, with three rectal glands.

The molecular results indicated that the PCR obtained were a band of approximately $1,000 \mathrm{bp}$ in all the samples analyzed, coinciding with the positive control (Contracaecum multipapillatum) (Fig. 4). The sequencing of the PCR products showed that the nematodes obtained in the three coastal lagoons of the southwest of the Gulf of Mexico (Navachiste, Colorada-Santa María-La Reforma Beach, and Ceuta) belong to Contracaecum multipapillatum with a 97$100 \%$ genetic identity.

\section{DISCUSSION}

The risk connected with the presence of nematode is of high relevance and economic impact, especially for species as mullet fish (Mugil cephalus). The results obtained in our work are in accordance with other authors, the which's stated that the parasitic infection can increase from moderate to severe levels depending on the quality of water (Shamsi et al., 2018), and which factors such as pollution and changes in marine ecology (temperature, light, decrease of intermediate hosts, presence of definitive hosts in the environment, among others) can affect significantly (Guerrero et al., 2017). The parasitic prevalence of nematodes was determined in three coastal lagoons of the southern Gulf of California. A parasitic prevalence of $67 \%$ was found, like that reported by Guerrero (2017), who found a pre- 
Table 1. Morphometric parameters of the striped mullet (Mugil cephalus). FC: condition factor; HIS: hepatosomatic index.

\begin{tabular}{lcccccc}
\hline Lagoon & Size $(\mathrm{cm})$ & Weight $(\mathrm{g})$ & Males & Females & FC & HSI \\
\hline Navachiste & $29.08 \pm 1.81$ & $384 \pm 12.75$ & 20 & 10 & $1.17-1.93$ & $0.85-1.45$ \\
La Reforma & $28.65 \pm 2.51$ & $379 \pm 24.65$ & 20 & 10 & $1.13-2.20$ & $0.81-1.32$ \\
Ceuta & $22.46 \pm 1.62$ & $300 \pm 39.95$ & 15 & 15 & $1.95-4.07$ & $0.81-1.37$ \\
\hline
\end{tabular}

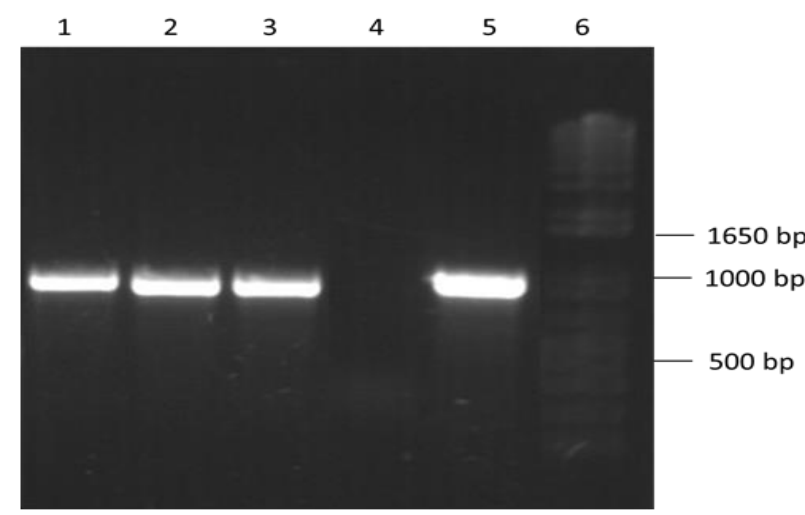

Figure 4. Molecular identification of nematodes obtained from three lagoon systems of the southern Gulf of California with primers NC5 and NC2 were: 1) Navachiste, 2) Colorada-Santa María-La Reforma, 3) Ceuta, 4) negative control 5) positive control (Contracaecum multipapillatum) 6) $1 \mathrm{~Kb}$ molecular weight marker.

valence of nematode parasites of $68 \%$ in the striped mullet at La Arenilla wetland, La Punta, Callao, Peru (Iannacone et al., 2010). They evaluated the community structure of Sciaena deliciosa parasites in Lima, Peru, finding a prevalence of nematode parasites of 60\%. Pardo-Gandarillas et al. (2009) registered parasitic prevalence above $70 \%$ in Dosidicus gigas, south of Central Chile. The average intensity and abundance of nematodes found in our work of 7.45 and 4.97, respectively, was superior to the found by Guerrero et al. (2017), who reported an average intensity of $2.6 \pm 1.19$ parasites/infected fish. This level of parasitism can be attributed to the ability to feed on very low-quality material and the first trophic level to obtain energy (Salinas-López et al., 2010; Dankwa et al., 2015; Villanueva-Gómez et al., 2016).

Our work were not significant differences in the number of nematodes in the striped mullet of the three coastal lagoons, which could be due to the human impact on the aquatic environment, as the influence of organic waste coming from the great agricultural development practiced in the zone and its surroundings, which affect the health of the resident aquatic fauna and favors the development of nematodes species present in these bodies of water.
A strong positive correlation of $0.756(P=0.000)$ was found between the number of nematodes with the size and weight of the fish, which coincides with that reported by Rawson Jr. (1976) and Cabrera \& Trillo (2004), who mentions that the diversity of parasites increases with the size of the age of the host during the time of exposure. This same pattern was observed in $M$. cephalus sampled at the confluence of the Colorado and Hardy Rivers, Baja California, Mexico (Valles-Ríos, 2000).

No significant differences were found between the number of parasites and sex of the organism, that is, they are parasitized equally; it could be inferred that the infections would be mainly related with the type of diet and the habitat of the host, as indicated in his work Pardo-Gandarilla et al. (2009).

The analysis of nematode parasites by tissue revealed that the highest number of nematodes was found in the abdominal cavity, results that coincide with that reported by Ruiz \& Vallejo (2013), who found $80 \%$ of nematodes in the abdominal cavity and $20 \%$ was found in liver, spleen, and vertebrae. BrachoEspinoza et al. (2013), detected the presence of parasites of the Anisakidae family in $100 \%$, in the abdominal cavity of the species (Mugil liza, M. curema, M. insilis and Eugerres spp.). Salinas-López et al. (2010) found a greater number of parasites in the liver (120) and muscle (49), while in the intestine did not locate parasites. These results highlight the preference of the nematode to establish itself inside the host.

Another parameter analyzed was the condition factor (FC), where values of 1.17-4.07 were obtained, which are within the ranges reported for other fish, such as mojarra (Caquetaia kraussii), moncholo (Hoplias malabaricus), cachegua (Trachycorystes insignis), pacora (Plagioscion magdalenae) and liso (Rhamdia sebae) (Arellano-Martínez et al., 2001; González \& Oyarzún, 2002; Horbowy et al., 2016), indicating a good nutritional status of the organisms analyzed. Schmid et al. (1999), consider that a fish with good nutritional status has a FC equal to or greater than one. HSI variations obtained, between 0.85 and 1.45 , may be associated with the reproductive activity of the fish at the time of sampling (Arellano-Martínez et al., 2001) and not degenerative liver alterations caused by the 
presence of nematodes in fish. Both the FC and the HSI are relevant data because they help to compare and quantify numerically the condition or state in which the fish were at the time of sampling (Collins \& Anderson, 1995; Lambert \& Dutil, 1997). In our work, the correlation between both factors was negative $-0.452(P$ $=0.012)$, which means that, for this species, these variables analyzed together are not adequate to express the nutritional and health status of the fish.

The nematode identified taxonomically in this work was Contracaecum multipapillatum, which belongs to the Anisakidae family, whose larvae are capable of infesting the human digestive tract after accidental ingestion, producing the disease known as anisakidosis (Audicana et al., 2002; Gómez et al., 2006; Barros et al., 2008; Jaramillo-Colorado et al., 2015). Nematodes do not become adults in humans, but their antigens can be recognized by the immune system, in addition to provoking allergic reactions (Salazar-Bermúdez et al., 2012); the fact that worms have also been found in muscle (fillet or fish market) implies a risk to human health if consumed raw, undercooked, "ceviche brine". The results of the molecular characterization of the nematodes in the three coastal lagoons were positive to the C. multipapillatum; this coincides with the results observed in the morphological identification. Similar results obtained Valles-Vega (2014) and Zhu et al. (2000). Finally, it is important to highlight that this work constitutes the first parasitological record for this fish species in the three Mexican coastal lagoons. For this reason, our results on the parasitic prevalence allowed us to diagnose this euryhaline fish sanitary status.

\section{REFERENCES}

Arellano-Martínez, M., Rojas-Herrera, A., GarcíaDomínguez, F., Ceballos-Vázquez, B.P. \& VillalejoFuerte, M. 2001. Ciclo reproductivo del pargo lunarejo Lutjanus guttatus (Steindachner, 1869) en las costas de Guerrero, México. Revista de Biología Marina y Oceanografía, 36(1): 1-8. doi: 10.4067/S0718-1957 2001000100001

Ashfield, L.A., Pottinger, T.G. \& Sumpter, J.P. 1998. Exposure of female juvenile rainbow trout to alkylphenol compounds results in modifications to growth and ovosomatic index. Environmental Toxicology and Chemistry, 17(3): 679-686. doi: 10.1002/etc. 5620170423

Audicana, M.T., Ansotegui, L., Fernández de Corres, L. \& Kennedy, M.W. 2002. Anisakis simplex: dangerous - dead and alive? Trends in Parasitology, 18: 20-25. doi: 10.1016/S1471-4922(01)02152-3
Ayala-Bocos, A., Reyes-Bonilla, H., Calderón-Aguilera, L.E., Herrero-Perezrul, M.D. \& González-Espinos, P.C. 2016. Forecasting changes in sea surface temperature in the Gulf of California, and their effects on abundance and distribution of reef species. Revista Ciencias Marinas y Costeras, 8(1): 29-40. doi: 10.15359/revmar.8-1.2

Barros, C., Manzarbeitia, F. \& López-Vélez, R. 2008. Reactividad alérgica a Anisakis simplex y su asociación con asma bronquial en niños escolares del estado Nueva Esparta, Venezuela. Boletín de Malariología y Salud Ambiental, 48(2): 145-152.

Bracho-Espinoza, H., Molina, J.D., Pirona, M. \& Cordero, M. 2013. Nematodos de la familia Anisakidae en productos de la pesca, faja costera Médano Blanco. Revista Científica de la Facultad de Ciencias Veterinarias, 23(2): 163-167.

Cabrera, R. \& Trillo, A.P. 2004. Anisakidosis: ¿una zoonosis parasitaria marina desconocida o emergente en el Perú? Revista de Gastroenterología del Perú, 24: 335- 342.

Cabrera-Páez, Y., Aguilar-Betancourt, C. \& GonzálezSansón, G. 2008. Indicadores morfológicos y reproductivos del pez Gambusia puncticulata (Poeciliidae) en sitios muy contaminados del río Almendares, Cuba. Revista de Biología Tropical, 56(4): 1991-2004. doi: 10.15517/rbt.v56i4.5774

Castellanos, J.A., Tangua, A.R., Mercado, R. \& Salazar, L. 2017. Anisakidae nematodes isolated from the flathead grey mullet fish (Mugil cephalus) of Buenaventura, Colombia. International Journal for Parasitology: Parasites and Wildlife, 6: 265-270. doi: 10.1016/j.ijppaw.2017.08.001

Castellanos, J.A., Tangua, A.R. \& Salazar, L. 2018. First reporting of Anisakis sp. in the armed snook fish (Centropomus armatus) caught and commercialized in Buenaventura, Colombia. Infection, 22(3): 136-140. doi: 10.22354/in.v22i3.724

Collins, A.L. \& Anderson, T.A. 1995. The regulation of endogenous energy stores during starvation and refeeding in the somatic tissues of the golden perch. Journal of Fish Biology, 47: 1004-1015.

Colín-Martínez, A. 2014. Variabilidad y estructura genética de la lisa Mugil cephalus en Golfo de México y el Pacífico mexicano. Tesis de Maestría en Biología, Universidad Autónoma Metropolitana, Iztapalapa, 86 pp.

Dankwa, H., Blay, J. \& Yankson, K. 2015. Food and feeding habits of grey mullets (Pisces: Mugilidae) in two estuaries in Ghana. West African Journal of Applied Ecology, 8(1): 1-13. doi: 10.4314/wajae. v8i1.45786

Dione, E.N., Diouf, M., Fall, J. \& Ba, C.T. 2014. Seasonal and spatial distribution of nematode larvae of the genera Anisakis and Contracaecum (Anisakidae) in 
two populations of Mugil cephalus (Mugilidae) from Saloum and Senegal rivers. Journal of Biology and Life Science, 5: 41-56. doi: 10.5296/jbls.v5i1.4685

Fernández, C. 2014. Variación estacional e interanual de la dieta de la lisa, Mugil cephalus Linnaeus, 1758, frente a Callao $\left(12^{\circ} \mathrm{S}\right)$, en 2005 y 2013. Ecología Aplicada, 13(2): 211-223.

Gaber, A.R., El Garhy, M. \& Morsy, K. 2015. Prevalence and intensity of helminth parasites of African catfish Clarias gariepinus in Lake Manzalah, Egypt. Advances in Bioscience and Biotechnology, 6(7): 464469. doi: 10.4236/abb.2015.67048

González, P. \& Oyarzún, C. 2002. Variabilidad de índices biológicos en Pinguipes chilensis Valenciennes 1833 (Perciformes, Pinguipedidae): ¿están realmente correlacionados? Gayana Botánica, 66(2): 249-253. doi: 10.4067/S0717-65382002000200023

Gómez, J., Gérez, M., Zangróniz, M., Muro, E., González, T. \& García, M. 2006. Reacciones de hipersensibilidad y manifestaciones digestivas producidas por la ingestión de pescado parasitado por Anisakis simplex. Semergen, 25: 792-797.

Guerrero, P.M., Torres, S., López, A., Ríos, L. \& Echevarría, D. 2017. Intensidad y prevalencia de parásitos en dedinos de Mugil cephalus (Linnaeus, 1758) en el humedal la arenilla, La Punta, Callao. XXVI Reunión Científica-ICBAR, Facultad de Ciencias Biológicas de la Universidad Nacional Mayor, pp. 9-11.

Herrera-Valdivia, E., López-Martínez, J., Castillo-Vargas, S. \& García-Juárez, A.R. 2016. Diversidad taxonómica y funcional en la comunidad de peces de la pesca de arrastre de camarón en el norte del Golfo de California, México. Revista de Biología Tropical, 64(2): 587-602. doi: 10.15517/rbt.v63i3.15852

Horbowy, J., Podolska, M. \& Nadolna-Ałtyn, K. 2016. Increasing occurrence of anisakid nematodes in the liver of cod (Gadus morhua) from the Baltic Sea: does infection affect the condition and mortality of fish? Fisheries Research, 179: 98-103. doi: 10.1016/j. fishres.2016.02.011

Iannacone, J., Morón, L. \& Guizado, S. 2010. Variación entre años de la fauna de parásitos metazoos de Sciaena deliciosa (Tschudi, 1846) (Perciformes: Sciaenidae) en Lima, Perú. Latin American Journal of Aquatic Research, 38(2): 218-226. doi: 10.4067/ S0718-560X2010000200006

Jaramillo-Colorado, B.E., Arroyo-Salgado, B. \& RuizGarcés, L.C. 2015. Organochlorine pesticides and parasites in Mugil incilis collected in Cartagena Bay, Colombia. Environmental Science and Pollution Research, 22: 17475-17485. doi: 10.1007/s11356-0154986-5

Lambert, Y. \& Dutil, J.D. 1997. Can simple condition indices be used to monitor and quantify seasonal changes in the energy reserves of Atlantic cod (Gadus morhua)? Canadian Journal of Fisheries and Aquatic Sciences, 54(1): 104-112. doi: 10.1139/f96-149

Maldonado, S.G. \& Godoy, R.M. 2014. Helmintos parásitos de peces de agua dulce introducidos. In: Mendoza, R.A \& Koleff, P. (Eds.). Especies acuáticas invasoras en México. Comisión Nacional para el Conocimiento y Uso de la Biodiversidad, Ciudad de México, pp. 270-272.

Marín, E.B.J., Quintero, A., Bussière, D. \& Dodson, J.J. 2003. Reproduction and recruitment of white mullet (Mugil curema) to a tropical lagoon (Margarita Island, Venezuela) as revealed by otolith microstructure. Fishery Bulletin, 101: 809-821.

Martins, M.L., Onaka, E.M. \& Fenerick, J. 2005. Larval Contracaecum sp. (Nematoda: Anisakidae) in Hoplias malabaricus and Hoplerythrinus unitaeniatus (Osteichthyes: Erythrinidae) of economic importance in occidental marshlands of Maranhão, Brazil. Veterinary Parasitology, 127(1): 51-59. doi: 10.1016/j. vetpar.2004.09.026

Martins, M., Fenerick Jr., J., Nomura, D. \& Braga, F. 2018. Prevalence, intensity, and seasonality of Ichthyouris voltagrandensis (Nematoda: Pharyngodonidae) in Myleus tiete (Osteichthyes: Characidae) from Volta Grande Reservoir, Minas Gerais State, Brazil. Boletim do Instituto de Pesca, 29(1): 39-46.

Montes, A., González-Farías, F. \& Botello, A. 2011. Pollution by organochlorine pesticides in NavachisteMacapule, Sinaloa, Mexico. Environmental Monitoring and Assessment, 184: 1359-1369. doi: 10.1007/ s10661-011-2046-2

Padilla-Serrato, J., López-Martínez, J., RodríguezRomero, J., Acevedo-Cervantes, A., Galván-Magaña, F. \& Lluch-Cota, D. 2017. Changes in fish community structures in a coastal lagoon in the Gulf of California, México. Revista de Biología Marina y Oceanografía, 52(3): 567-579. doi: 10.4067 /S0718-19572017000 300013

Pardo-Gandarillas, M.C., Lorhmann, K., Valdivia, A.L. \& Ibáñez, C.M. 2009. First record of parasites of Dosidicus gigas (d'Orbigny, 1835) (Cephalopoda: Ommastrephidae) from the Humboldt Current System off Chile. Revista de Biología Marina y Oceanografía, 44: 397-408. doi: 10.4067/S0718-195720090002000 13

Rawson Jr., M.V. 1976. Biología de la población de parásitos del salmonete rayado, Mugil cephalus L.I. Monogenea. Journal of Fish Biology, 9: 185-194.

Romero-Beltrán, E., Aldana-Flores, G., Muñoz-Mejía, E.M., Medina-Osuna, P.M., Valdez-Ledón, P., BectValdez, J.A., Gaspar-Dillanes, M.T., HuidobroCampos, L., Romero-Correa, A., Figueroa, A., Saucedo-Barrón, C.J., Osuna-Bernal, D.A. \& RomeroMendoza, N. 2014. Estudio de la calidad del agua y 
sedimento en lagunas costeras del estado de Sinaloa, México. Instituto Nacional de la Pesca, Secretaría de Agricultura, Ganadería, Desarrollo Rural, Pesca y Alimentación, Mazatlán, 191 pp.

Ruiz, L. \& Vallejo, A. 2013. Parameters of infection by nematodes of the family Anisakidae that parasitize Parassi mullet (Mugil incilis) in the bay of Cartagena (Colombian Caribbean). Intropica, 8: 53-60.

Salazar-Bermúdez, M.A., Gómez del Prado-Rosas, M.C. \& Ascencio-Valle, F.J. 2012. Presencia de anticuerpos anti-Contracaecum multipapillatum (s.l.) como método diagnóstico de contracecosis en la población de La Paz, BCS., México. The Biologist, 10(2): 1-9.

Salinas-López, N., Javier, I.B.F., Lucio, G.S. \& Roberto, M. 2010. Parásitos de Mugil cephalus (Lisa) en centros comerciales del área metropolitana de Monterrey. Memoria de XII Congreso Nacional de Ciencia y Tecnología de Alimentos, Universidad Autónoma de Nuevo León, Nuevo León.

Salvarina, I., Koutrakis, E. \& Leonardos, I. 2018. Comparative study of feeding behaviour of five Mugilidae species juveniles from two estuarine systems in the North Aegean Sea. Journal of the Marine Biological Association of the United Kingdom, 98(2): 283-297.

Sánchez-Lindoro, F.J., Jiménez-Illescas, A.R., EspinosaCarreón, T.L. \& Obeso-Nieblas, M. 2017. Modelo hidrodinámico en el Sistema Lagunar Navachiste, Guasave, Sinaloa, México. Revista de Biología Marina y Oceanografía, 52(2): 219-231. doi: 10.4067/S071819572017000200003

Schmidt, H., Bernet, D., Wahli, T., Meier, W. \& Burkhardt-Holm, P. 1999. Active biomonitoring with brown trout and rainbow trout in diluted sewage plant effluents. Journal of Fish Biology, 54: 585-596. doi:10.1111/j.1095-8649.1999.tb00637.x

Shamsi, S., Steller, E. \& Chen, Y. 2018a. New and known zoonotic nematode larvae within selected fish species from Queensland waters in Australia. International Journal of Food Microbiology, 272(2): 73-82. doi:10.1016/j.ijfoodmicro.2018.03.007

Shamsi, S., Turner, A. \& Wassens, S. 2017. Description and genetic characterization of a new Contracaecum larval type (Nematoda: Anisakidae) from Australia. Journal of Helminthology, 92: 216-222. doi:10.1017/ S0022149X17000360

Received: 20 March 2019; Accepted: 12 October 2019
Shamsi, S., Turner, A. \& Wassens, S. 2018b. Description and genetic characterization of a new Contracaecum larval type (Nematoda: Anisakidae) from Australia. Journal of Helminthology, 92(2): 1-7. doi: 10.1017/S0022149X17000360

Valles-Ríos, M.E., Ruiz-Campos, G. \& Galavíz-Silva, L. 2000. Prevalencia e intensidad parasitaria en Mugil cephalus (Pisces: Mugilidae), del Río Colorado, Baja California, México. Revista de Biología Tropical, 48(2-3): 495-501.

Valles-Vega, G.I., 2014. Estudio experimental de la infección de Contracaecum multipapillatum (Drasche, 1882) (sensu lato) (Nematoda: Anisakidae) en copépodos calanoides. Tesis de Maestría en Manejo de Recursos Marinos, Instituto Politécnico Nacional, 69 pp.

Valles-Vega, I., Molina-Fernández, D., Benítez, R., Hernández-Trujillo, S. \& Adroher, F.J. 2017. Early development and life cycle of Contracaecum multipapillatum s.l. from a brown pelican Pelecanus occidentalis in the Gulf of California, Mexico. Diseases of Aquatic Organisms, 125: 167-178. doi: 10.3354/dao03147

Verdiell-Cubedo, D., Egea-Serrano, A., Oliva-Paterna, F.J. \& Torralva, M. 2007. Biología trófica de los juveniles del género Liza (Pisces: Mugilidae) en la laguna costera del Mar Menor (SE Península Ibérica). Limnetica, 26(1): 67-73. doi: 10.23818/limn.26.06

Villanueva-Gómez, B.O. 2016. Alimento y hábitos alimentarios de Mugil cephalus "lisa" en la región La Libertad durante el año 2016. Tesis de Grado, Universidad Nacional de Trujillo, Trujillo, 58 pp.

Zhu, X., D'Amelio, S., Paggi, L. \& Gasser, R.B. 2000. Assessing sequence variation in the internal transcribed spacers of ribosomal DNA within and among members of the Contracaecum osculatum complex (Nematoda: Ascaridoidea: Anisakidae). Parasitology Research, 86(8): 677-683. doi: 10.1007/ PL00008551 